University of Nebraska - Lincoln

DigitalCommons@University of Nebraska - Lincoln

Publications, Agencies and Staff of the U.S.

Department of Commerce

U.S. Department of Commerce

2012

\title{
Linking ciguatera poisoning to spatial ecology of fish: A novel approach to examining the distribution of biotoxin levels in the great barracuda by combining non-lethal blood sampling and biotelemetry
}

\author{
Amanda C. O'Toole \\ Carleton University, amanda.c.otoole@gmail.com \\ Marie-Yasmine Dechraoui Bottein \\ Center for Coastal Environmental Health and Biomolecular Research \\ Andy J. Danylchuk \\ University of Massachusetts Amherst \\ John S. Ramsdell \\ Carleton University \\ Steven J. Cooke \\ Carleton University \\ Follow this and additional works at: https://digitalcommons.unl.edu/usdeptcommercepub \\ Part of the Environmental Sciences Commons
}

O'Toole, Amanda C.; Dechraoui Bottein, Marie-Yasmine; Danylchuk, Andy J.; Ramsdell, John S.; and Cooke, Steven J., "Linking ciguatera poisoning to spatial ecology of fish: A novel approach to examining the distribution of biotoxin levels in the great barracuda by combining non-lethal blood sampling and biotelemetry" (2012). Publications, Agencies and Staff of the U.S. Department of Commerce. 352. https://digitalcommons.unl.edu/usdeptcommercepub/352

This Article is brought to you for free and open access by the U.S. Department of Commerce at DigitalCommons@University of Nebraska - Lincoln. It has been accepted for inclusion in Publications, Agencies and Staff of the U.S. Department of Commerce by an authorized administrator of DigitalCommons@University of Nebraska - Lincoln. 


\title{
Linking ciguatera poisoning to spatial ecology of fish: A novel approach to examining the distribution of biotoxin levels in the great barracuda by combining non-lethal blood sampling and biotelemetry
}

\author{
Amanda C. O'Toole a,*, Marie-Yasmine Dechraoui Bottein ${ }^{\mathrm{b}}$, Andy J. Danylchuk ${ }^{\mathrm{c}}$, \\ John S. Ramsdell ${ }^{\mathrm{b}}$, Steven J. Cooke ${ }^{\mathrm{a}, \mathrm{d}}$ \\ a Fish Ecology and Conservation Physiology Laboratory, Department of Biology, Carleton University, 1125 Colonel By Dr., Ottawa, Ontario, Canada K1S 5B6 \\ ${ }^{\mathrm{b}}$ Marine Biotoxins Program, Center for Coastal Environmental Health and Biomolecular Research, NOAA, National Ocean Service, Charleston, SC 29412, USA \\ ${ }^{c}$ Department of Environmental Conservation, University of Massachusetts Amherst, Amherst, MA 01003-9285, USA \\ d Institute of Environmental Science, Carleton University, 1125 Colonel By Dr., Ottawa, Ontario, Canada K1S 5B6
}

\section{A R T I C L E I N F O}

\section{Article history:}

Received 5 July 2011

Received in revised form 16 November 2011

Accepted 17 November 2011

Available online 3 May 2012

Disclaimer: This publication does not constitute an endorsement of any commercial product or intend to be an opinion beyond scientific or other results obtained by the National Oceanic and Atmospheric Administration (NOAA). No reference shall be made to NOAA, or this publication furnished by NOAA, to any advertising or sales promotion which would indicate or imply that NOAA recommends or endorses any proprietary product mentioned herein, or which has as its purse an interest to cause the advertised product to be used or purchased because of this publication.

\section{Keywords:}

Ciguatoxin

Acoustic telemetry

Non-lethal blood sample

Marine biotoxins

Functional bioassay

Spatial ecology

\begin{abstract}
A B S T R A C T
Ciguatera in humans is typically caused by the consumption of reef fish that have accumulated Ciguatoxins (CTXs) in their flesh. Over a six month period, we captured 38 wild adult great barracuda (Sphyraena barracuda), a species commonly associated with ciguatera in The Bahamas. We sampled three tissues (i.e., muscle, liver, and blood) and analysed them for the presence of ciguatoxins using a functional in vitro N2A bioassay. Detectable concentrations of ciguatoxins found in the three tissue types ranged from 2.51 to 211.74 pg C-CTX- 1 equivalents $/ \mathrm{g}$. Blood and liver toxin concentrations were positively correlated $(\rho=0.86, P=0.003)$, indicating that, for the first time, blood sampling provides a non-lethal method of detecting ciguatoxin in wild fish. Non-lethal blood sampling also presents opportunities to couple this approach with biotelemetry and biologging techniques that enable the study of fish distribution and movement. To demonstrate the potential for linking ciguatoxin occurrence with barracuda spatial ecology, we also present a proof-of-concept case study where blood samples were obtained from 20 fish before releasing them with acoustic transmitters and tracking them in the coastal waters using a fixed acoustic telemetry array covering $44 \mathrm{~km}^{2}$. Fish that tested positive for CTX may have smaller home ranges than non-toxic fish (median distance travelled, $\mathrm{U}=2.21, \mathrm{P}=0.03$ ). Results presented from this study may help identify high risk areas and source-sink dynamics of toxins, potentially reducing the incidence and human health risk of ciguatera fish poisoning. Moreover, development of the non-lethal sampling approach and measurement of ciguatera from blood provide future opportunities to understand the mechanistic relationship between toxins and the spatial ecology of a broad range of marine fish species.
\end{abstract}

(c) 2012 Elsevier B.V. All rights reserved.

\section{Introduction}

Ciguatera fish poisoning is a type of human poisoning caused by the consumption of reef fish contaminated with ciguatoxins (CTXs) that occurs in tropical and subtropical regions of the Caribbean Sea, Pacific Ocean, and Indian Ocean (Lehane and Lewis, 2000; Dickey and Plakas,

Abbreviations: CTX, ciguatoxin; C-CTX, Caribbean ciguatoxin; MDT, median distance travelled; MLD, minimum linear distance; TE, tissue equivalents.

* Corresponding author. Tel.: +1 613520 4377; fax: +1 6135203539.

E-mail address: amanda.c.otoole@gmail.com (A.C. O'Toole).
2010). It is estimated that more than 25,000 cases of ciguatera fish poisoning are reported worldwide every year (Lewis, 2001) and may cause severe and potentially long-lasting human health effects including gastrointestinal distress, neurological disturbances, and occasional cardiovascular problems (Swift and Swift, 1993; Lehane and Lewis, 2000; Lewis, 2001). CTX is produced by dinoflagellates (genus Gambierdiscus) often found inhabiting warm, shallow waters in association with various macroalgal species or in recently disturbed or altered marine habitats (Yasumoto et al., 1977; Bagnis et al., 1980; Lewis, 1986; Ruff, 1989; Grzerbyk et al., 1994). CTX produced by Gambierdiscus spp. biomagnifies through marine food webs reaching peak concentrations in apex predators such as great barracuda (Sphyraena barracuda), snappers 
(Lutjanus spp.), moray eel (Gymnothorax spp.) or jacks (Caranx spp., Vernoux et al., 1985; Randall, 1958; Lewis and Holmes, 1993). The toxin is typically most concentrated in visceral tissue (Vernoux et al., 1985; Swift and Swift, 1993), yet relative distribution of CTXs in liver versus muscle may vary significantly within and between fish species and between tissues within an individual fish. For example, in the Pacific, moray eels with high toxicity detected in liver present low to nonsignificant toxin concentrations in their flesh (Yasumoto and Satake, 1996; Helfrich et al., 1968). As well, the average toxin concentration ratio of liver to flesh is found as high as 43:1 in green moray eels (Gymnothorax funebris) collected in the French Caribbean (Vernoux et al., 1985). In contrast, other groups including Scombridae and Carangidae showed a liver to flesh ratio for CTX of around 2:1, and those fish generally accumulated ciguatoxins mainly in their muscle (Vernoux et al., 1985).

Many challenges are associated with the prediction, diagnosis, and treatment of ciguatera poisoning, especially within island and coastal communities that are highly affected due to reliance on reef fish as a main protein source (Lewis, 1986, 2001). Ciguatoxin is odourless and colourless, and the origin of a particular fish at the time of sale or ingestion is often unknown (Lewis, 1986; de Sylva, 1994). Moreover, low concentrations often make its detection difficult and there remains a need for a reliable method to help identify and prevent consumption of contaminated fish. Laboratory analyses have been developed to effectively detect the presence and concentration of CTXs, however these methods traditionally require invasive procedures and lethal sampling of tissues such as liver and muscle (Pottier et al., 2003; Bottein Dechraoui et al., 2005; 2007; Lewis et al., 1999, 2009). Thus, there is a need to develop a non-lethal sampling technique that will enable researchers to understand the ecological correlates associated with the accumulation of CTXs in marine fish.

Very little is known about the behavioural ecology (i.e., spatial ecology and foraging habits) of great barracuda and currently there is a lack of ecological studies conducted on fish contaminated with CTXs. Non-lethal sample collection combined with behavioural studies (i.e., telemetry) is a reasonably recent innovation that has the potential to elucidate the ecology of free-living wild fish (Cooke et al., 2008). Great barracuda are commonly associated with ciguatera fish poisoning due to their ecological position as apex reef predators and nearshore accessibility for anglers and subsistence fishers (Lewis and Holmes, 1993; de Sylva, 1994; Dunaway, 2008). Monitoring the behaviour of highrisk species such as great barracuda in the wild, while simultaneously determining if they have been exposed to CTXs will help improve the understanding of the occurrence and geographical distribution of CTX. Various anecdotal reports have led to the belief that great barracuda caught in some areas are unsuitable for consumption, whereas fish captured in adjacent areas are considered safe to eat by humans (e.g., inside of a reef versus outside, on one side of an island versus the other). Without an explicit understanding of the links between toxin accumulation and fish spatial ecology, it is questionable whether ciguatoxins are accumulated locally or if it is acquired elsewhere by migratory fish that move into the local area. The primary objective of the study was to identify a non-lethal sampling method for detection of ciguatoxin in wild fish. We also present a case study to demonstrate the potential for using nonlethal tissue sampling to link great barracuda spatial ecology to the occurrence of CTXs. Given the novelty of this approach, we consider this to be a proof-of-concept study as opposed to an exhaustive study. It is our hope that this work will stimulate future research using the techniques developed and tested here.

\section{Material and methods}

\subsection{Field sampling}

Between August 2008 and February 2009, adult great barracuda $(n=38)$ were captured off the coast of Cape Eleuthera, The Bahamas $\left(24^{\circ} 54^{\prime} \mathrm{N} ; 76^{\circ} 20^{\prime} \mathrm{W}\right)$. Located along the edge of the Grand Bahama Bank at the junction of the deep Exuma Sound, the waters surrounding Cape Eleuthera support a range of habitat types including tidal flats, mangrove creeks, patch reefs, seagrass beds, and deeper offshore environments. All barracuda were captured by trolling with artificial lures and heavy action recreational fishing gear (i.e., $14 \mathrm{~kg}$ [30 lb] test fishing line; details in O'Toole et al., 2010a, 2010b), apart from two barracuda liver samples obtained from a local fisherman who had captured the fish within the study area. Upon landing, the fish were held in a large cooler and placed into a supine position while a $2 \mathrm{ml}$ blood sample was obtained via caudal venipuncture using a $3 \mathrm{ml}$ vacutainer (lithium heparin coated; B-D Inc, New Jersey) and $3.8 \mathrm{~cm}$ (1.5") 21 gauge needle (Fig. 1). The blood sampling process typically required $<1 \mathrm{~min}$ to complete. Blood samples were immediately placed in an ice-water slurry and transferred to Eppendorf tubes (in replicate) upon return from the field $(<3 \mathrm{~h}$ post-collection). One replicate was refrigerated and the other was frozen in an ultracold $-80{ }^{\circ} \mathrm{C}$ freezer. All fish were measured for total length. Of the 38 great barracuda included in the study, 30 were sampled for blood and 11 barracuda were lethally sampled to obtain whole liver and/or muscle $(\geq 1 \mathrm{~g})$ samples. Liver and muscle biopsies were not taken from released individuals. All liver and muscle samples were frozen in an ultracold $-80^{\circ} \mathrm{C}$ freezer until ready for toxin analysis.

\subsection{CTX analysis}

Blood aliquots $(100 \mu \mathrm{l})$ were vortex-mixed for $1 \mathrm{~min}$ with three volumes of acetonitrile then stored for $15 \mathrm{~min}$ at $-20^{\circ} \mathrm{C}$ to facilitate protein precipitation. Samples were then centrifuged for $15 \mathrm{~min}$ at $3000 \times g$, at $4{ }^{\circ} \mathrm{C}$. The supernatant was collected, dried under nitrogen flux, and resuspended in $100 \%$ methanol. This method of ciguatoxin extraction from whole blood samples was found to recover $62 \%$ of the Caribbean ciguatoxin C-CTX-1 (Bottein Dechraoui et al., 2007).

Ciguatoxin from tissue samples were extracted as previously described (Murata et al., 1990; Lewis et al., 1991; Bottein Dechraoui et al., 2005) with some modifications. Tissues were minced and extracted in acetone ( $3 \mathrm{ml} / \mathrm{g}$ of tissue) by homogenization, probe sonication on ice ( $1 \mathrm{~min}$ ), and centrifugation for $5 \mathrm{~min}$ at $3000 \times \mathrm{g}$. Supernatants were collected and pellets were again extracted by vortex mixing for $30 \mathrm{~s}$, sonication for $1 \mathrm{~min}$ and centrifugation as described above. Both supernatants were combined in glass test tubes and dried under nitrogen flux at $50{ }^{\circ} \mathrm{C}$. The dried residue was dissolved in $3 \mathrm{ml}$ of 90\% aqueous methanol by sonicating and vortex mixing and the aqueous methanol was extracted twice with $3 \mathrm{ml}$ n-hexane by vortex mixing and phase separation by

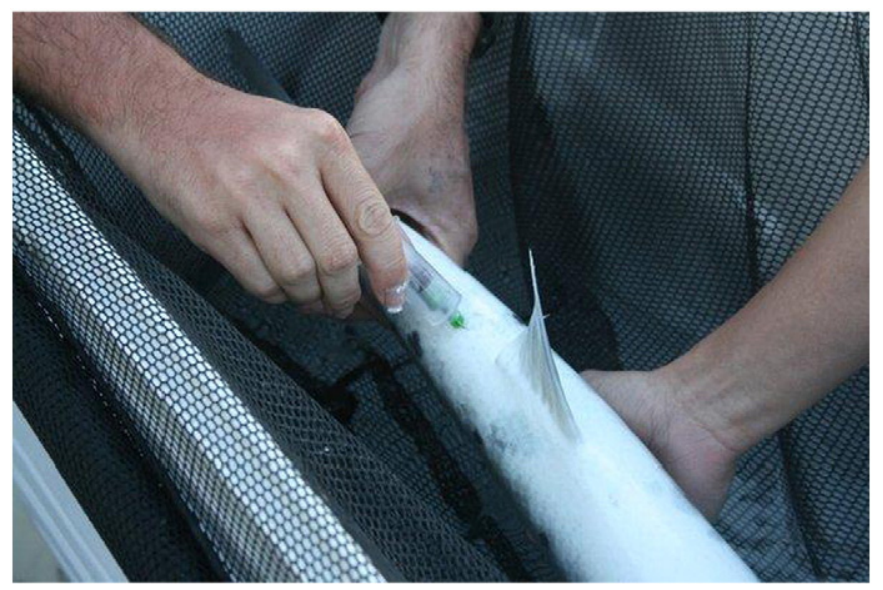

Fig. 1. Photograph of a blood sample being obtained from a great barracuda (S. barracuda) via caudal venipuncture using a $3 \mathrm{ml}$ lithium heparin vacutainer and $3.8 \mathrm{~cm}\left(1.5^{\prime \prime}\right) 21$ gauge needle. 
gravity. Both methanol fractions were combined and dried under nitrogen as described above. The dried residue was dissolved in $3 \mathrm{ml}$ of $25 \%$ aqueous ethanol by sonication and vortex mixing, and extracted twice with an equal volume of diethyl ether. The diethyl ether layers were combined and evaporated under gentle nitrogen flux and resuspended in methanol in Varian screw cap vials at a concentration of $2 \mathrm{~g}$ tissue equivalents $/ \mathrm{ml}$, and stored at $-20{ }^{\circ} \mathrm{C}$ until analysis. Toxin recovery from fish using similar method was estimated at 63\% (Lewis, 2003; Lewis and Sellin, 1993).

Methanolic extracts were analysed using the functional bioassay N2A cytotoxicity assay following a modified version of the method developed by Manger et al., in, 1993 (Dechraoui et al., 1999; Bottein Dechraoui et al., 2005). C-CTX-1 standard (generously given by $\mathrm{R}$. Dickey, FDA) or samples, resuspended in $\mathrm{MeOH}$, were directly added to ouabain/veratridine $(0.5 / 0.05 \mathrm{mM})$ pretreated mouse neuroblastome cells (N2A) plated in a $100 \mu$ total volume of medium (RPMI supplemented with $5 \%$ FBS). Sodium channel dependent toxic activity was assessed to ensure specificity of the assay by additionally testing each sample in the absence of ouabain/veratridine (results not shown). After an 18-20 h incubation cell viability was assessed using MTT tetrazolium salt. With the exception of the analysis of four blood samples (for which sample size was limited), assays were repeated at a minimum of three-times with each run in duplicate, as previously described (Dechraoui et al., 1999; Bottein Dechraoui et al., 2005). Data were analysed with GraphPad Prism version 4.00 (GraphPad Software, San Diego, CA) and sample concentration was expressed as C-CTX-1 equivalents. The detection limit in tissue was estimated to be $0.32 \mathrm{pg} / \mathrm{gTE}$.

\subsection{Acoustic telemetry}

An acoustic telemetry array consisting of 53 autonomous receivers (VR2 and VR2W; Vemco/Amirix Systems, Shad Bay, NS) was deployed off the coast of Cape Eleuthera. Receiver stations were established in a range of habitat types, positioned in three curtains projecting out from Powell Point with receivers placed in a net formation between the curtains and along the edge of the continental shelf (Fig. 2A). The entire array covered an area of approximately $44 \mathrm{~km}^{2}$. Range tests indicated that receivers deployed in shallow, coastal habitats ( $>1 \mathrm{~m}$ deep) had an average detection radius of $250 \mathrm{~m}$ and receivers placed in deeper areas (i.e., mid-array) had an average coverage radius of 500-600 m.

A subset of the barracuda that were captured and blood sampled were tagged with acoustic transmitters ( $n=20$; V16, V9AP; Vemco/ Amirix Systems, Shad Bay, NS). Not all barracuda captured during the study were implanted and released with transmitters due to small body size of some fish or extreme water temperatures $\left(>29^{\circ} \mathrm{C}\right.$ may have increased the probability of surgical or post-release mortality). Following blood sampling, these individuals were transferred to a 1001 cooler infused with a dosage of 3-aminobenzoic acid ethyl ester (MS222) that would cause the fish to lose equilibrium (approximately $100 \mathrm{mg} / \mathrm{l}$ ). A small $2-3 \mathrm{~cm}$ incision was cut along the ventral midline of the fish, midway between the pelvic and anal fins. The disinfected transmitter was placed intracoelomically and the incision closed using 2-3 simple interrupted sutures (PDS II 3/0 absorbable sutures, Ethicon Ltd, NJ; Cooke et al., 2003). Fresh seawater was added to dilute the anaesthetic concentration in the cooler beginning halfway through the surgery in order to begin the revival process and each fish was allowed to recover for 30-60 min with consistent water changes. Once recovered (i.e., able to independently maintain equilibrium), the barracuda were released back into the array. Fish were tracked until the last receiver download was completed on October 27, 2009 (up to 321 days). All handling and surgical procedures conformed to the guidelines of the Canadian Council for Animal Care administered through Carleton University, Ottawa, ON.

\subsection{Data analysis}

A Spearman rank correlation analysis was conducted to test for association between ranked CTX concentrations of the three tissue types (i.e., liver, muscle, blood) and with total length of each fish. To determine the duration each barracuda was present within the confines of the array, a residency index $\left(I_{R}\right)$ was calculated by dividing the number of days an individual was detected by the number of days at large. $\mathrm{I}_{\mathrm{R}}$ values range from 0 to 1 , with 0 indicating low residency and 1 indicating 100\% residency within the array. Home range was estimated by determining the median distance travelled (MDT) and the minimum linear distance (MLD) for each individual barracuda (Chapman et al., 2005). MDT was calculated by finding the median value of the distances between the most frequently visited receiver to all other receivers visited within the array. MLD was calculated by measuring the distance between the two most distant receivers that each individual visited. Spearman rank correlation analysis was used to determine if blood CTX was associated with spatial movement (i.e., $I_{R}$, MDT, MLD). A Mann Whitney U test was used to compare median spatial movement metrics (i.e., $\left.I_{R}, M D T, M L D\right)$ between fish that tested positive for toxin presence and fish that tested negative (fish U48, U53, U54, and U55 were not included in the analysis because they were not detected after $24 \mathrm{~h}$ post-release, Table 2). All statistical testing was completed using JMP 8.0 (SAS Institute, SC) and results were assessed at $\alpha=0.05$.

\section{Results}

\subsection{Ciguatoxin assay}

Of the 12 liver samples collected, 11 samples tested positive for CTX, ranging from 4.96 to $167.77 \mathrm{pg} / \mathrm{g}_{\mathrm{TE}}$ with a median value of $21.58 \mathrm{pg} / \mathrm{g}$ (mean, $31.7 \pm 14.1 \mathrm{pg} / \mathrm{g}_{\mathrm{TE}}$ ). The only liver sample that was below the detection limit $\left(0.32 \mathrm{pg} / \mathrm{g}_{\mathrm{TE}}\right)$ was obtained from fish U58 (Table 1). Eight out of twelve muscle samples tested positive for CTX, with concentrations ranging between 2.51 and $98.83 \mathrm{pg} / \mathrm{g}_{\mathrm{TE}}$ and a median value of $5.58 \mathrm{pg} / \mathrm{g}_{\mathrm{TE}}$ (mean, $19.06 \pm 11.6 \mathrm{pg} / \mathrm{g}_{\mathrm{TE}}$ ). When sampled for both tissues, individual barracuda had equivalent or lower toxin concentrations in muscle than in the associated liver sample (Table 1). Over the entire sampling period, 30 blood samples were drawn from barracuda, and 18 of these samples tested positive for CTX. Blood toxin concentrations from the positive samples ranged from 3.07 to $211.74 \mathrm{pg} / \mathrm{ml}$ and the median value was $13.75 \mathrm{pg} / \mathrm{ml}$ (mean, $25.26 \pm 11.2 \mathrm{pg} / \mathrm{ml}$, Table 1). Fish U70 had the highest concentration of toxin in blood $(211.74 \mathrm{pg} / \mathrm{ml})$. Spearman rank correlation analysis showed that CTX concentrations in fish blood and liver were positively correlated $(\rho=0.86, P=0.003)$. Although muscle and liver toxin concentration correlations were not statistically significant $(\rho=0.58, P=0.078)$, a potential association may exist had there been a larger sample size available for these tissues. Mean size of sampled barracuda was $86.5 \pm 2.2 \mathrm{~cm}$ (total length ranging from 60 to $120 \mathrm{~cm}$, Table 1). Toxin concentrations were not correlated with fish total length $(\mathrm{P}>0.05)$.

\subsection{Spatial ecology}

All barracuda were captured within the footprint of the telemetry array, although the majority of individuals $(n=14)$ that showed detectable levels of CTX in their tissues were generally captured within the western portion of the array, in deeper water along the edge of the continental shelf (Fig. 2B). Tagged barracuda with detectable CTX concentrations in blood tended to stay within the western section of the array, along the coast and just around the end of Powell Point (Fig. 2A).

Of all barracuda released with transmitters during the study period, $I_{R}$ values ranged from 0.02 to 0.72 , with a median value of $0.08(n=14)$ and a mean value of $0.17 \pm 0.06$ (median $\mathrm{I}_{\mathrm{R}}$ : CTX positive fish, 0.06 ; CTX 

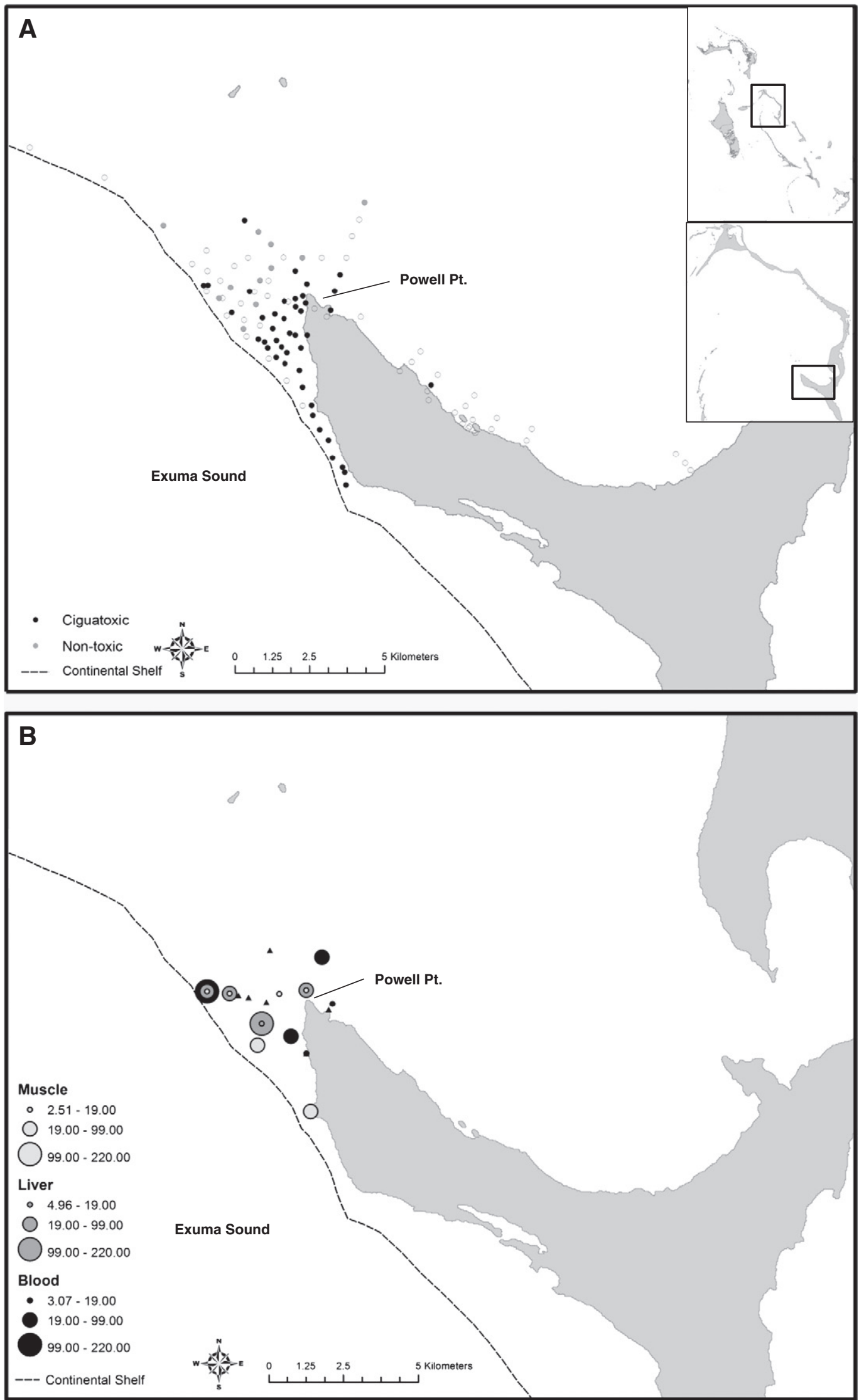

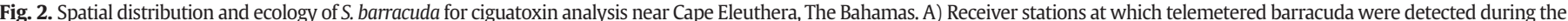

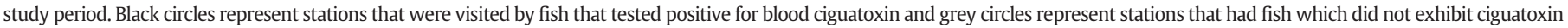

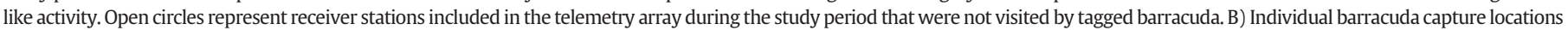
with associated muscle, liver, and blood CTX concentrations ( $\mathrm{pg} / \mathrm{ml}$ ). Black filled triangles represent capture locations for barracuda that did not test positive for CTX. 
Table 1

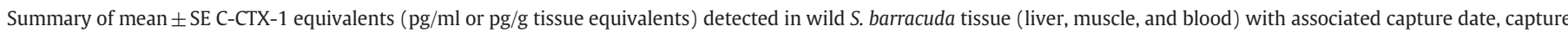

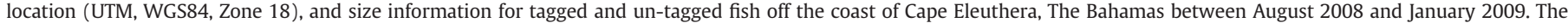
detection limit was estimated at $0.32 \mathrm{pg} / \mathrm{gTE}$.

\begin{tabular}{|c|c|c|c|c|c|c|c|c|c|c|c|}
\hline \multirow{2}{*}{$\begin{array}{l}\text { Fish } \\
\text { ID }\end{array}$} & \multirow[t]{2}{*}{ Capture date } & \multirow{2}{*}{$\begin{array}{l}\mathrm{TL} \\
(\mathrm{cm})\end{array}$} & \multicolumn{2}{|c|}{ Capture location } & \multirow{2}{*}{$\begin{array}{l}\text { Liver } \\
\text { mean } \pm \mathrm{SE}\end{array}$} & \multirow[t]{2}{*}{$\mathrm{N}$} & \multirow{2}{*}{$\begin{array}{l}\text { Muscle } \\
\text { mean } \pm \mathrm{SE}\end{array}$} & \multirow[t]{2}{*}{$\mathrm{N}$} & \multirow{2}{*}{$\begin{array}{l}\text { Blood } \\
\text { mean } \pm \text { SE }\end{array}$} & \multirow[t]{2}{*}{$\mathrm{N}$} & \multirow[t]{2}{*}{ Tagged } \\
\hline & & & $\mathrm{X}$ & $\mathrm{Y}$ & & & & & & & \\
\hline $\mathrm{U} 22$ & Aug-23-2008 & 74 & 364,258 & $2,744,213$ & $\mathrm{~N} / \mathrm{A}$ & & $21.74 \pm 1.76$ & 4 & $9.85 \pm 1.7$ & 4 & $\mathrm{~N}$ \\
\hline $\mathrm{U} 23$ & Aug-26-2008 & 86 & 364,986 & $2,747,818$ & N/A & & $\mathrm{N} / \mathrm{A}$ & & $16.36 \pm 1.38$ & 3 & $\mathrm{~N}$ \\
\hline $\mathrm{U} 24$ & Aug-26-2008 & 66 & 364,227 & $2,744,741$ & $\mathrm{~N} / \mathrm{A}$ & & $\mathrm{N} / \mathrm{A}$ & & $<\mathrm{dl}$ & & $\mathrm{N}$ \\
\hline $\mathrm{U} 25$ & Aug-26-2008 & 109 & 364,110 & $2,746,151$ & $\mathrm{~N} / \mathrm{A}$ & & $\mathrm{N} / \mathrm{A}$ & & $15 \pm 0.84$ & 3 & $\mathrm{~N}$ \\
\hline $\mathrm{U} 26$ & Aug-26-2008 & 92 & 363,915 & $2,747,613$ & $\mathrm{~N} / \mathrm{A}$ & & $\mathrm{N} / \mathrm{A}$ & & $<\mathrm{dl}$ & & $\mathrm{N}$ \\
\hline U35 & Aug-26-2008 & 84 & 362,464 & $2,746,422$ & $\mathrm{~N} / \mathrm{A}$ & & $98.83 \pm 14.09$ & 4 & $\mathrm{~N} / \mathrm{A}$ & & $\mathrm{N}$ \\
\hline U37 & Aug-25-2008 & 98 & 364,106 & $2,748,277$ & $41.05 \pm 7.46$ & 3 & $11.43 \pm 0.65$ & 4 & $9.7 \pm 1.63$ & 3 & $\mathrm{~N}$ \\
\hline U38 & Dec-10-2008 & 101 & 362,763 & $2,747,876$ & $\mathrm{~N} / \mathrm{A}$ & & $\mathrm{N} / \mathrm{A}$ & & $<\mathrm{dl}$ & & $\mathrm{Y}$ \\
\hline U39 & Dec-12-2008 & 120 & 364,855 & $2,747,621$ & $\mathrm{~N} / \mathrm{A}$ & & $\mathrm{N} / \mathrm{A}$ & & $\mathrm{N} / \mathrm{A}$ & & $\mathrm{Y}$ \\
\hline U40 & Dec-12-2008 & 94 & 362,168 & $2,748,033$ & $\mathrm{~N} / \mathrm{A}$ & & $\mathrm{N} / \mathrm{A}$ & & $<\mathrm{dl}$ & & $\mathrm{Y}$ \\
\hline U41 & Dec-12-2008 & 83 & 362,168 & $2,748,033$ & $\mathrm{~N} / \mathrm{A}$ & & $\mathrm{N} / \mathrm{A}$ & & $<\mathrm{dl}$ & & $\mathrm{Y}$ \\
\hline $\mathrm{U} 42$ & Dec-13-2008 & 96 & 361,534 & $2,748,166$ & $\mathrm{~N} / \mathrm{A}$ & & $\mathrm{N} / \mathrm{A}$ & & $5.87 \pm 0.33$ & 3 & $\mathrm{Y}$ \\
\hline U43 & Dec-13-2008 & 62 & 361,534 & $2,748,166$ & $\mathrm{~N} / \mathrm{A}$ & & $\mathrm{N} / \mathrm{A}$ & & $<\mathrm{dl}$ & & $\mathrm{Y}$ \\
\hline U44 & Dec-13-2008 & 80 & 361,534 & $2,748,166$ & $\mathrm{~N} / \mathrm{A}$ & & $\mathrm{N} / \mathrm{A}$ & & $14.87 \pm 1.42$ & 4 & $\mathrm{Y}$ \\
\hline U45 & Dec-13-2008 & 94 & 361,534 & $2,748,166$ & $\mathrm{~N} / \mathrm{A}$ & & $\mathrm{N} / \mathrm{A}$ & & $12.7 \pm 0.79$ & 3 & $\mathrm{Y}$ \\
\hline U46 & Dec-13-2008 & 79 & 361,534 & $2,748,166$ & $\mathrm{~N} / \mathrm{A}$ & & $\mathrm{N} / \mathrm{A}$ & & $9.84 \pm 2.5$ & 3 & $\mathrm{Y}$ \\
\hline U47 & Dec-13-2008 & 81 & 361,534 & $2,748,166$ & $\mathrm{~N} / \mathrm{A}$ & & $\mathrm{N} / \mathrm{A}$ & & $15.96 \pm 3.96$ & 3 & $\mathrm{Y}$ \\
\hline U48 & Dec-13-2008 & 103 & 361,832 & $2,748,105$ & $\mathrm{~N} / \mathrm{A}$ & & $\mathrm{N} / \mathrm{A}$ & & $\mathrm{N} / \mathrm{A}$ & & $\mathrm{Y}$ \\
\hline U49 & Dec-13-2008 & 92 & 362,880 & $2,749,613$ & $\mathrm{~N} / \mathrm{A}$ & & $\mathrm{N} / \mathrm{A}$ & & $<\mathrm{dl}$ & & $\mathrm{Y}$ \\
\hline U50 & Dec-13-2008 & 79 & 362,464 & $2,746,422$ & $\mathrm{~N} / \mathrm{A}$ & & $\mathrm{N} / \mathrm{A}$ & & $7.65 \pm 1.3$ & 3 & $\mathrm{Y}$ \\
\hline U51 & Dec-13-2008 & 99 & 363,601 & $2,746,718$ & $\mathrm{~N} / \mathrm{A}$ & & $\mathrm{N} / \mathrm{A}$ & & $48.89 \pm 0.48$ & 2 & $\mathrm{Y}$ \\
\hline U52 & Dec-14-2008 & 79 & 360,637 & $2,748,227$ & $\mathrm{~N} / \mathrm{A}$ & & $\mathrm{N} / \mathrm{A}$ & & $<\mathrm{dl}$ & & $\mathrm{Y}$ \\
\hline U53 & Dec-14-2008 & 60 & 364,258 & $2,744,213$ & $\mathrm{~N} / \mathrm{A}$ & & $\mathrm{N} / \mathrm{A}$ & & $<\mathrm{dl}$ & & $\mathrm{Y}$ \\
\hline U54 & Dec-14-2008 & 99 & 364,110 & $2,746,151$ & $\mathrm{~N} / \mathrm{A}$ & & $\mathrm{N} / \mathrm{A}$ & & $8.48 \pm 1.32$ & 4 & $\mathrm{Y}$ \\
\hline U55 & Dec-15-2008 & 112 & 364,633 & $2,749,380$ & $\mathrm{~N} / \mathrm{A}$ & & $\mathrm{N} / \mathrm{A}$ & & $\mathrm{N} / \mathrm{A}$ & & $\mathrm{Y}$ \\
\hline U56 & Dec-15-2008 & 81 & 364,633 & $2,749,380$ & $\mathrm{~N} / \mathrm{A}$ & & $\mathrm{N} / \mathrm{A}$ & & $\mathrm{N} / \mathrm{A}$ & & $\mathrm{Y}$ \\
\hline U57 & Dec-15-2008 & 85.5 & 364,633 & $2,749,380$ & $\mathrm{~N} / \mathrm{A}$ & & $\mathrm{N} / \mathrm{A}$ & & $24.83 \pm 2.81$ & 4 & $\mathrm{Y}$ \\
\hline U58 & Dec-13-2008 & 80 & 361,534 & $2,748,166$ & $<\mathrm{dl}$ & & $<\mathrm{dl}$ & & $\mathrm{N} / \mathrm{A}$ & & $\mathrm{N}$ \\
\hline U69 & Jan-14-2009 & 84 & 360,783 & $2,748,241$ & $23.55 \pm 3.09$ & 3 & $2.6 \pm 0.53$ & 3 & $18.47 \pm 4.16$ & 4 & $\mathrm{~N}$ \\
\hline U70 & Jan-14-2009 & 94 & 360,783 & $2,748,241$ & $27.86 \pm 1.51$ & 3 & $5.62 \pm 1.43$ & 3 & $211.74 \pm 109.31$ & 2 & $\mathrm{~N}$ \\
\hline U71 & Jan-18-2009 & 72 & 361,534 & $2,748,166$ & $21.58 \pm 4.17$ & 4 & $<\mathrm{dl}$ & & $6.6 \pm 0.1$ & 2 & $\mathrm{~N}$ \\
\hline U72 & Jan-18-2009 & 68.5 & 361,534 & $2,748,166$ & $26.69 \pm 1.93$ & 6 & $2.51 \pm 0.25$ & 3 & $14.8 \pm 3.32$ & 2 & $\mathrm{~N}$ \\
\hline U73 & Jan-22-2009 & 80 & 361,534 & $2,748,166$ & $5.22 \pm 0.84$ & 3 & $<\mathrm{dl}$ & & $<\mathrm{dl}$ & & $\mathrm{N}$ \\
\hline U74 & Jan-22-2009 & 103 & 361,534 & $2,748,166$ & $5.6 \pm 0.59$ & 3 & $<\mathrm{dl}$ & & $<\mathrm{dl}$ & & $\mathrm{N}$ \\
\hline U75 & Jan-23-2009 & 85 & 363,187 & $2,748,150$ & $4.96 \pm 1.07$ & 4 & $5.54 \pm 1.42$ & 5 & $<\mathrm{dl}$ & & $\mathrm{N}$ \\
\hline U76 & Jan-24-2009 & 71 & 361,534 & $2,748,166$ & $6.25 \pm 1.19$ & 4 & $4.2 \pm 0.35$ & 5 & $3.07 \pm 0.84$ & 3 & $\mathrm{~N}$ \\
\hline U77 & Jan-17-2009 & 80 & 362,603 & $2,747,144$ & $18.22 \pm 2.89$ & 3 & $\mathrm{~N} / \mathrm{A}$ & & $\mathrm{N} / \mathrm{A}$ & & $\mathrm{N}$ \\
\hline U78 & Jan-17-2009 & 80 & 362,603 & $2,747,144$ & $167.77 \pm 26.72$ & 3 & $\mathrm{~N} / \mathrm{A}$ & & $\mathrm{N} / \mathrm{A}$ & & $\mathrm{N}$ \\
\hline
\end{tabular}

$<$ dl: below detection limit; N/A: no samples available; tagged: yes (Y) or no (N).

Table 2

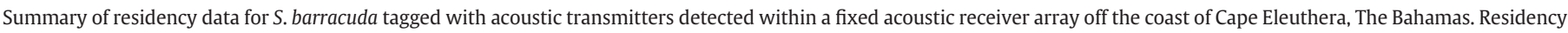
index $\left(\mathrm{I}_{\mathrm{R}}\right)$ was calculated by dividing the \# days detected by the \# days at large. Individuals that tested positive for C-CTX-1 equivalents are represented in bold.

\begin{tabular}{|c|c|c|c|c|c|c|c|c|}
\hline Fish ID & Tag ID & Date tagged & $\mathrm{TL}(\mathrm{cm})$ & Total detections ${ }^{\mathrm{a}}$ & \# days in array ${ }^{b}$ & \# days detected ${ }^{\mathrm{b}}$ & \# days at large & $\mathrm{I}_{\mathrm{R}}$ \\
\hline U38 & 79 & Dec-10-2008 & 101 & 161 & 9 & 7 & 321 & 0.02 \\
\hline U39 & 222 & Dec-12-2008 & 120 & 843 & 10 & 10 & 65 & 0.15 \\
\hline U40 & 228 & Dec-12-2008 & 94 & 355 & 5 & 5 & 65 & 0.08 \\
\hline U41 & 152 & Dec-12-2008 & 83 & 823 & 116 & 80 & 160 & 0.50 \\
\hline U42 & 9523 & Dec-13-2008 & 96 & 4568 & 318 & 50 & 318 & 0.16 \\
\hline U43 & 204 & Dec-13-2008 & 62 & 129 & 105 & 20 & 105 & 0.19 \\
\hline U44 & 9529 & Dec-13-2008 & 80 & 234 & 168 & 38 & 318 & 0.12 \\
\hline U45 & 80 & Dec-13-2008 & 94 & 2226 & 304 & 21 & 318 & 0.07 \\
\hline U46 & 150 & Dec-13-2008 & 79 & 88 & 4 & 4 & 160 & 0.03 \\
\hline U47 & 148 & Dec-13-2008 & 81 & 30 & 117 & 8 & 160 & 0.05 \\
\hline $\mathrm{U} 48$ & 1440 & Dec-13-2008 & 103 & 0 & 1 & 1 & 318 & 0.00 \\
\hline U49 & 220 & Dec-13-2008 & 92 & 2297 & 75 & 47 & 65 & 0.72 \\
\hline U50 & 206 & Dec-13-2008 & 79 & 1 & 101 & 2 & 101 & 0.02 \\
\hline U51 & 1441 & Dec-13-2008 & 99 & 13,761 & 317 & 106 & 318 & 0.33 \\
\hline U52 & 224 & Dec-14-2008 & 79 & 151 & 4 & 3 & 65 & 0.05 \\
\hline U53 & 202 & Dec-14-2008 & 60 & 0 & 1 & 1 & 95 & 0.01 \\
\hline U54 & 226 & Dec-14-2008 & 99 & $\mathbf{0}$ & 1 & 1 & 65 & 0.02 \\
\hline U55 & 9522 & Dec-15-2008 & 112 & 0 & 1 & 1 & 316 & 0.00 \\
\hline U56 & 254 & Dec-15-2008 & 81 & 2414 & 22 & 20 & 95 & 0.21 \\
\hline U57 & 208 & Dec-15-2008 & 85.5 & 67 & 4 & 4 & 95 & 0.04 \\
\hline
\end{tabular}

a Detections during the first $24 \mathrm{~h}$ are not included in the total detections tally.

b Number of days in the array and number of days detected include the first $24 \mathrm{~h}$ post-release. 
negative fish, 0.14). Median MDT for all tagged barracuda was $1006 \mathrm{~m}$ ( $\mathrm{n}=14$; mean, $1259 \pm 355 \mathrm{~m}$ ), with the largest range of movement of up to 4989 m (median MDT: CTX positive fish, 506 m; CTX negative fish, $1773 \mathrm{~m}$ ). Overall, tagged barracuda had a median MLD value of $3314 \mathrm{~m}$ (mean, $3248 \pm 701 \mathrm{~m}$ ) and some fish moved up to $7460 \mathrm{~m}$ across the array area (median MLD; CTX positive fish, 1115 m; CTX negative fish, $5176 \mathrm{~m}$ ) (Table 3).

Spearman correlation analysis showed that $I_{R}, M L D$, and MDT were not correlated with blood CTX concentrations $\left(I_{R}, \rho=-0.05\right.$, $\mathrm{P}=0.85$; MLD, $\rho=-0.13, \mathrm{P}=0.62$; MDT, $\rho=-0.37, \mathrm{P}=0.16)$. Median MDT values between fish that did and did not test positive for CTX were significantly different $(U=2.21, P=0.03)$. Thus, when compared to fish that did not have detectable blood CTX, tagged barracuda that tested positive for the blood toxin presence may have had smaller home range sizes within the confines of the telemetry array, although larger sample sizes will be required to confirm this result (CTX positive fish, $n=8$, CTX negative fish $n=6$ ). Median $I_{R}$ and MLD values were similar between fish with detectable amounts of toxin and fish without detectable tissue toxin amounts $\left(I_{R}, U=0.97\right.$, $\mathrm{P}=0.33$; MLD, $\mathrm{U}=1.49, \mathrm{P}=0.12$ ).

\section{Discussion}

For the first time, ciguatoxin-like activity was detected from a nonlethal blood sample extracted from a wild fish. Past studies have shown C-CTX concentrations extracted from barracuda muscle and liver range from below the detection limit to $>50 \mathrm{ppb}$ C-CTX-1 equivalents (Pottier et al., 2003; Bottein Dechraoui et al., 2005; Villareal et al., 2007). We found that great barracuda blood toxin concentrations are also comparable to concentrations detected in liver samples, where a high blood toxin level, such as that documented in the present study, may be an indicator of recent exposure due to consumption of toxic prey and consequent distribution and accumulation of ciguatoxin within other tissues. Within a given region, it is not unusual for reef fish to have variable toxin levels that may reflect metabolism, accumulation rate, detoxification rate, or foraging behaviour of an individual fish (Tosteson et al., 1988; Lewis and Holmes, 1993).

Great barracuda with higher toxin concentrations in our study were captured along the portion of the array that lies west of Cape Eleuthera, typically along the continental shelf. These areas are typically characterised by deeper water and a mosaic of fringing reefs, large patch reefs, and sandy substrate and are also highly accessible to local artisanal fishers, potentially elevating the risk of ciguatera within the local community. Local residents within the region believe that some of the reef areas along south Eleuthera (i.e., west side of the telemetry array) represent high risk regions for fish harbouring CTX and that consumption of larger fish is more likely to be associated with ciguatera fish poisoning (A. O'Toole and A. Danylchuk, personal observation). The same belief that barracuda from deeper reef areas are more likely to result in ciguatera fish poisoning is also common on other islands in The Bahamas and Caribbean (A. Danylchuk, personal observation). However, we did not detect a relationship between toxin concentration and fish size (size distribution in the present study was similar to historical size distributions reported from Bimini, The Bahamas and Miami, FL; de Sylva, 1963). The most toxic samples from each of the three tissue types were obtained from fish that ranged from 80 to $94 \mathrm{~cm}$ in total length, a size range that is often regarded locally as safe for consumption (O'Toole, personal observation). Although the majority of the samples extracted from fish during this study contained concentrations too low to intoxicate humans (in the U.S., action levels for ciguatera are being listed at $0.01 \mathrm{ppb}$ for Pacific ciguatoxin and $0.1 \mathrm{ppb}$ for Caribbean ciguatoxin; Fish and Fishery Products Hazards and Controls Guidance April, 2011), there remains a potential risk due to successive low doses that may lead to intoxication or result in intensification or reoccurrence of previous symptoms (Lewis, 1986; Dickey and Plakas, 2010).

In general, very little is known about great barracuda basic biology and only recently has the extent of barracuda behaviour and spatial ecology been assessed using telemetry devices (O'Toole et al., 2010a, 2010b, 2011). Apart from a study by Villareal et al. (2007) that evaluated the presence of Gambierdiscus toxicus on oil platforms in the Gulf of Mexico and compared barracuda movement information garnered from course-scale mark-recapture data, researchers have not, until now, attempted to link the occurrence of ciguatoxin with spatial ecology of high-risk species. For the first time, with the ability to detect toxin concentrations in non-lethal blood samples that are comparable to other tissues (i.e., liver), we were able to tag and thus study barracuda spatial ecology in the wild while at the same time provide a potential link to ciguatoxin occurrence. Barracuda with detectable concentrations of CTX may have smaller home ranges within the confines of the telemetry array. Variability in fish toxicity within and between sampling sites is common (Dierking and Campora, 2009) and home ranges of individual fish may overlap with high-risk areas. In our study, toxin accumulation may have occurred along the edge of the continental shelf in the

Table 3

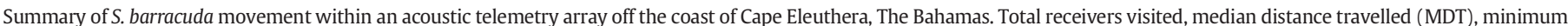

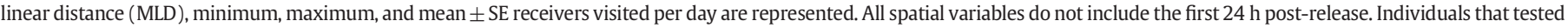
positive for C-CTX-1 equivalents are bolded.

\begin{tabular}{|c|c|c|c|c|c|c|c|c|c|}
\hline Fish ID & Tag ID & \# receivers & $\mathrm{X}$ & Y & MDT (m) & $\operatorname{MLD}(\mathrm{m})$ & Min receivers & Max receivers & Mean receivers $\pm S E$ \\
\hline U38 & 79 & 9 & $18,362,763$ & $2,747,876$ & 1926 & 5037 & 1 & 5 & $2.50 \pm 0.67$ \\
\hline U39 & 222 & 5 & $18,364,855$ & $2,747,621$ & 1870 & 2724 & 1 & 5 & $2.89 \pm 0.35$ \\
\hline $\mathrm{U} 40$ & 228 & 7 & $18,362,168$ & $2,748,033$ & 449 & 1407 & 1 & 5 & $3.25 \pm 0.76$ \\
\hline U41 & 152 & 14 & $18,362,168$ & $2,748,033$ & 1173 & 2897 & 1 & 6 & $1.59 \pm 0.11$ \\
\hline U42 & 9523 & 3 & $18,361,534$ & $2,748,166$ & 563 & 898 & 1 & 2 & $1.10 \pm 0.04$ \\
\hline U43 & 204 & 5 & $18,361,534$ & $2,748,166$ & 1621 & 5318 & 1 & 1 & $1.00 \pm 0.00$ \\
\hline U44 & 9529 & 1 & $18,361,534$ & $2,748,166$ & $\mathbf{0}$ & 0 & 1 & 1 & $1.00 \pm 0.00$ \\
\hline U45 & 80 & 5 & $18,361,534$ & $2,748,166$ & 1577 & 5711 & 1 & 3 & $1.15 \pm 0.11$ \\
\hline U46 & 150 & 6 & $18,361,534$ & $2,748,166$ & 449 & 1331 & 3 & 5 & $3.67 \pm 0.67$ \\
\hline U47 & 148 & 1 & $18,361,534$ & $2,748,166$ & 0 & 0 & 1 & 1 & $1.00 \pm 0.00$ \\
\hline U48 & 1440 & 0 & $18,361,832$ & $2,748,105$ & 0 & 0 & 0 & 0 & 0 \\
\hline U49 & 220 & 12 & $18,362,880$ & $2,749,613$ & 2477 & 5949 & 1 & 6 & $1.98 \pm 0.19$ \\
\hline U50 & 206 & 1 & $18,362,464$ & $2,746,422$ & o & 0 & 1 & 1 & $1.00 \pm 0.00$ \\
\hline U51 & 1441 & 37 & $18,363,601$ & $2,746,718$ & 1558 & 7460 & 1 & 10 & $4.71 \pm 0.27$ \\
\hline U52 & 224 & 3 & $18,360,637$ & $2,748,227$ & 4989 & 5729 & 1 & 3 & $2.00 \pm 1.41$ \\
\hline U53 & 202 & 0 & $18,364,258$ & $2,744,213$ & 0 & 0 & 0 & 0 & 0 \\
\hline U54 & 226 & 0 & $18,364,110$ & $2,746,151$ & 0 & 0 & 0 & $\mathbf{0}$ & 0 \\
\hline U55 & 9522 & 0 & $18,364,633$ & $2,749,380$ & 0 & 0 & 0 & 0 & 0 \\
\hline U56 & 254 & 20 & $18,364,633$ & $2,749,380$ & 1392 & 4395 & 1 & 14 & $7.32 \pm 1.00$ \\
\hline U57 & 208 & 10 & $18,364,633$ & $2,749,380$ & 838 & 3730 & 1 & 8 & $4.67 \pm 2.03$ \\
\hline
\end{tabular}


western portion of the array, an area that is characterised by a mosaic of deep patch reefs that could possibly harbour toxin-producing organisms. Ciguatera-causing dinoflagellates have also been found in association with drift algae samples, further illustrating the potential for spatial distribution of ciguatoxin throughout The Bahamas, Caribbean Sea, and Floridian waters (Bomber et al., 1988). However, toxin origin and accumulation remain unclear as tagged barracuda are able to move outside of the range of the receivers (as evidenced by a 5\% median residency estimation) and are known to travel great distances (Villareal et al., 2007) including forays to other islands within the Bahamian Archipelago before returning near to the site of original capture (O'Toole et al., 2011) and to locations in southern Florida (O'Toole and Danylchuk, unpublished data).

\section{Conclusions and future directions}

Our study is the first report of non-lethal sampling of wild fish for ciguatoxin analysis and will enable future research to address a variety of questions that currently make it difficult to fully characterise the risks of ciguatera. For example, non-lethal blood sampling provides opportunities to identify temporal aspects of ciguatoxin dynamics because fish can be serially sampled (e.g., once a month over the course of a year) if they can be recaptured in the wild or held in the lab or field enclosures. Blood CTX concentrations may be a good indicator of recent exposure to ciguatoxins and thus, could provide a useful application for fishing area surveillance and ciguatera risk prevention. Our study also represents one of the first attempts to combine toxin measures with fish behaviour. Cooke et al. (2008) advocated for using biotelemetry and biologging techniques as the backbone for integrative studies that incorporate other aspects of fish condition including those that can be obtained from non-lethal blood samples. Non-lethal biopsy of fish for blood (or other tissues including small muscle and gill samples) prior to electronic tagging has been used to evaluate correlates of migration failure in Pacific salmon (e.g., Cooke et al., 2006; Crossin et al., 2009) and the correlates of catch-and-release mortality and behavioural impairments in largemouth bass (Thompson et al., 2008). In addition, biopsy approaches have been validated and such non-lethal sampling as we conducted here has been shown to not influence mortality or behaviour of large, adult teleosts (i.e., Pacific salmon, Cooke et al., 2005). Our work serves as a proof-of-concept study that we hope will stimulate future research that combines non-lethal biopsies to evaluate biotoxin concentrations with biotelemetry or biologging tools to evaluate the spatial ecology of fish. Given the inherent variability in both biotoxin concentrations and movements among individuals, we suggest that future studies should attempt to use larger sample sizes based on a priori power analyses.

Additionally, seasonal fluctuations of ciguatoxin in barracuda not only have been reported by Tosteson et al. (1988) in Puerto Rico, but also refuted by de Sylva (1994) in data collected from southern Florida. Seasonal association between water temperature and toxic fish was not apparent in the present study, although we did not sample barracuda year-round and such a result should be considered inconclusive at this time. Clearly additional work is needed to understand the temporal and seasonal patterns of ciguatoxin dynamics in wild fish.

Due to the spatial limitations of a fixed telemetry array in our study (i.e., fish could swim outside of the array footprint), a more in-depth evaluation of barracuda movement and behaviour could potentially be provided by using pop-up satellite tags. Information obtained from future electronic tagging studies that incorporate non-lethal biopsy to quantify ciguatoxin should provide insight to regional and speciesspecific risk evaluation and prevention. Combining knowledge of fish movement with toxin levels and blooms of Gambierdiscus spp. will contribute to the future management and use of marine resources and local risk assessment.

\section{Acknowledgements}

The authors would like to acknowledge the staff and volunteers at the Cape Eleuthera Institute and The Island School. Thank you to K. Murchie, K. Hanson, A. Shultz, C. Haak, E. Brooks, and C. Suski for field and laboratory assistance. Four reviewers from the Marine Biotoxins Program, Center for Coastal Environmental Health and Biomolecular Research provided comments on an early version of the manuscript. The Bahamas Department of Marine Resources provided scientific collection permits and animal care approval was obtained from the Canadian Council on Animal Care through Carleton University. The receiver array was partially supported by grants from Bonefish and Tarpon Trust, the Charles A. and Anne Morrow Lindbergh Foundation, and the Baldwin Foundation. Additional financial support was provided by Ontario Ministry of Research and Innovation (through an Early Researcher Award to S.J.C.), the Canada Foundation for Innovation, the Canada Research Chairs Program, and Carleton University. A.J.D. was supported by the National Institute of Food \& Agriculture, U.S. Department of Agriculture, and the Massachusetts Agricultural Experiment Station and Department of Environmental Conservation (project number MAS00987).

\section{References}

Bagnis R, Chanteau S, Chunge E, Hurtel JM. Origins of ciguatera fish poisoning: a new dinoflagellate, Gambierdiscus toxicus Adachi and Fukuyo, definitively involved as a causal agent. Toxicon 1980;18:199-208.

Bomber JW, Morton SL, Babinchak JA, Norris DR, Morton JG. Epiphytic dinoflagellates of drift algae-another toxigenic community in the ciguatera food chain. Bull Mar Sci 1988;43:204-14.

Bottein Dechraoui MY, Tiedeken JA, Persad R, Wang Z, Granade HR, Dickey RW, et al. Use of two detection methods to discriminate ciguatoxins from brevetoxins: application to great barracuda from Florida Keys. Toxicon 2005;46:261-70.

Bottein Dechraoui MY, Wang Z, Ramsdell JS. Optimization of ciguatoxin extraction method from blood for Pacific ciguatoxin (P-CTX-1). Toxicon 2007;49:100-5.

Chapman DD, Pikitch EK, Babcock E, Shivji MS. Marine reserve design and evaluation using automated acoustic telemetry: a case-study involving coral reef-associated sharks in the Mesoamerican Caribbean. Mar Technol Soc J 2005;39:42-59.

Cooke SJ, Crossin GT, Patterson DA, English KK, Hinch SG, Young JL, et al. Coupling noninvasive physiological assessments with telemetry to understand inter-individual variation in behaviour and survivorship of sockeye salmon: development and validation of a technique. J Fish Biol 2005;67:1342-58.

Cooke SJ, Graeb BDS, Suski DC, Ostrand KG. Effects of suture material on incision healing growth and survival of juvenile largemouth bass implanted with miniature radio transmitters: case study of a novice and experienced fish surgeon. J Fish Biol 2003;62: 1366-80.

Cooke SJ, Hinch SG, Crossin GT, Patterson DA, English KK, Shrimpton JM, et al. Physiology of individual late-run Fraser River sockeye salmon (Oncorhynchus nerka) sampled in the ocean correlates with fate during spawning migration. Can J Fish Aquat Sci 2006;63:1469-80

Cooke SJ, Hinch SG, Farrell AP, Patterson DA, Miller-Saunders K, Welch DW, et al. Developing a mechanistic understanding of fish migrations by linking telemetry with physiology, behaviour, genomics and experimental biology: an interdisciplinary case study on adult Fraser River sockeye salmon. Fisheries 2008;33:321-38.

Crossin GT, Hinch SG, Welch DW, Cooke SJ, Patterson DA, Hills JA, et al. Physiological profiles of sockeye salmon in the northeastern Pacific Ocean and the effects of exogenous $\mathrm{GnRH}$ and testosterone on rates of homeward migration. Mar Freshw Behav Physiol 2009;42:89-108.

Dechraoui MY, Naar J, Pauillac S, Legrand AM. Ciguatoxins and brevetoxins, neurotoxic polyether compounds active on sodium channels. Toxicon 1999;37:125-43.

de Sylva DP. Systematics and life history of the great barracuda Sphyraena barracuda. Coral Gables, FL: University of Miami Press; 1963.

de Sylva DP. Distribution and ecology of ciguatera fish poisoning in Florida, with emphasis on the Florida Keys. Bull Mar Sci 1994;54:944-54.

Dickey RW, Plakas SM. Ciguatera: a public health perspective. Toxicon 2010;56: 123-36.

Dierking J, Campora CE. Ciguatera in the introduced fish Cephalopholis argus (Serranidae) in Hawai'i and implications for fishery management. Pac Sci 2009;63:193-204.

Dunaway V. Sportfish of Florida. Miami, FL: Wickstrom; 2008.

Fish and Fishery Products Hazards and Controls Guidance. 4th ed. Department of Health and Human Services, Public Health Service, Food and Drug Administration, Center for Food Safety and Applied Nutrition Office of Food Safety. April 2011. http://www.fda.gov/Food/GuidanceComplianceRegulatoryInformation/GuidanceDocuments/Seafood/FishandFisheriesProductsHazardsandControlsGuide/default. htm Accessed: June 14, 2011.

Grzerbyk D, Berland B, Thomassin BA, Bosi C, Arnoux A. Ecology of ciguateric dinoflagellates in the coral reef complex of Mayotte Island (S.W. Indian Ocean). J Exp Mar Biol Ecol 1994;178:51-66. 
Helfrich P, Piyakamchana T, Miles PS. The ecology of ciguateric reef fishes in the Line Islands. Occ Pap Bernice P Bishop Mus 1968;35:316-26.

Lehane L, Lewis RJ. Ciguatera: recent advances but the risk remains. Int J Food Microbio 2000;61:91-125.

Lewis ND. Disease and development: ciguatera fish poisoning. Soc Sci Med 1986;23:983-93.

Lewis RJ. The changing face of ciguatera. Toxicon 2001;39:97-106.

Lewis RJ. Detection of ciguatoxins. In: Hallegraeff GM, editor. UNESCO monographs on oceanographic methodology, manual on harmful marine microalgae. UNESCO; 2003. p. 253-63.

Lewis RJ, Holmes MJ. Origin and transfer of toxins involved in ciguatera. Comp Biochem Physiol C 1993;106:615-28.

Lewis RJ, Jones A, Vernoux JP. HPLC/tandem electrospray mass spectrometry for the determination of sub-ppb levels of Pacific and Caribbean ciguatoxins in crude extracts of fish. Anal Chem 1999;71:247-50.

Lewis RJ, Sellin M. Recovery of ciguatoxin from fish flesh. Toxicon 1993:31:1333-6.

Lewis RJ, Sellin M, Poli MA, Norton RS, MacLeod JK, Sheil MM. Purification and charac terization of ciguatoxins from moray eel (Lycodontis javanicus muraenidae) Toxicon 1991;29:1115-27.

Lewis RJ, Yang A, Jones A. Rapid extraction combined with LC-tandem mass spectrometry (CREM-LC/MS/MS) for the determination of ciguatoxins in ciguateric fish flesh. Toxicon 2009;54:62-6.

Manger RL, Leja LS, Lee SY, Hungerford JM, Wekell MM. Tetrazolium-based cell bioassay for neurotoxins active on voltage-sensitive sodium channels: semiautomated assay for saxitoxins, brevetoxins, and ciguatoxins. Anal Biochem 1993;214:190-4.

Murata M, Legrand AM, Ishibashi Y, Yasumoto T. Structures and configurations of ciguatoxin from the moray eel Gymnothorax javanicus and its likely precurso from the dinoflagellate Gambierdiscus toxicus. J Am Chem Soc 1990;112:4380-6.

O'Toole AC, Danylchuk AJ, Goldberg TL, Suski CD, Philipp DP, Brooks E, et al. Spatial ecology and residency patterns of adult great barracuda (Sphyraena barracuda) in coastal waters of The Bahamas. Mar Biol 2011;158:2227-37.
O'Toole AC, Danylchuk AJ, Suski CD, Cooke SJ. Consequences of catch-and-release angling on the physiological status, injury, and immediate mortality of great barracuda (Sphyraena barracuda) in The Bahamas. ICES J Mar Sci 2010a;67: 1667-75.

O'Toole AC, Murchie KJ, Pullen C, Hanson KC, Suski CD, Danylchuk AJ, et al. Locomotory activity and depth distribution of adult great barracuda (Sphyraena barracuda) in Bahamian coastal habitats determined using acceleration and pressure biotelemetry transmitters. Mar Freshw Res 2010b;61:1446-56.

Pottier I, Hamilton B, Jones A, Lewis RJ, Vernoux JP. Identification of slow and fastacting toxins in a highly ciguatoxic barracuda (Sphyraena barracuda) by HPLC/MS and radiolabelled ligand binding. Toxicon 2003;42:663-72.

Randall JE. A review of ciguatera, tropical fish poisoning, with a tentative explanation of its cause. Bull Mar Sci Gulf Caribb 1958;8:236-67.

Ruff TA. Ciguatera in the Pacific: a link with military activities. Lancet 1989;1:201-4.

Swift AEB, Swift TR. Ciguatera. J Toxicol Clin Toxicol 1993;3:1-29.

Thompson LA, Donaldson MR, Hanson KC, Arlinghaus R, Cooke SJ. Physiology, behaviour, and survival of angled and air-exposed largemouth bass. N Am J Fish Manage 2008;28:1059-68.

Tosteson TR, Ballantine DL, Durst HD. Seasonal frequency of ciguatoxic barracuda in southwest Puerto Rico. Toxicon 1988;26:795-801.

Vernoux JP, Lahlou N, Abbad El Andaloussi S, Riyeche N, Magras L. A study of the distribution of ciguatoxin in individual Caribbean fish. Acta Trop 1985;42:225-33.

Villareal TA, Hanson S, Qualia S, Jester ELE, Granade HR, Dickey RW. Petroleum production platforms as sites for the expansion of ciguatera in the northwestern Gulf of Mexico. Harmful Algae 2007;6:253-9.

Yasumoto T, Nakajima I, Bagnis R, Adachi R. Finding of a dinoflagellate as a likely culprit of ciguatera. Bull Jpn Soc Sci Fish 1977;43:1021-6.

Yasumoto T, Satake M. Chemistry, etiology and determination methods of ciguatera toxins. J Toxicol-Toxin Rev 1996;15:91-107. 